\title{
THE EVALUATION OF THE CONCENTRATIONS OF METHYLPREDNISOLONE APPLIED INTRAVENOUSLY AND BY IONTOPHORESIS IN THE PIG
}

ĐURĐEVIĆ S*, JEZDIMIROVIĆ MILANKA**, ĐUROVIĆ A*, DEDIĆ GORDANA*, ALEKSIĆ NEVENKA**, BRANKOVIĆ NATAŠA ${ }^{* * *}$, STOJILJKOVIĆ $S^{* * *}$, STOJŠIĆ $D^{*}$ and BLAGOJEVIĆ $Z^{* * * *}$

\footnotetext{
*Military Medical Academy, Belgrade, Serbia; **University of Belgrade, Faculty of Veterinary Medicine, Belgrade, Serbia; ${ }^{* \star *}$ Faculty of Sports and Physical Education, Niš, Serbia; $\star * \star *$ Institute for orthopaedic surgery "Banjica", Belgrade, Serbia
}

(Received 19. November 2008)

The current clinical research on pharmacokinetics of methylprednisolone was performed on male pigs to whom was administered either intravenously or locally, via iontophoresis. Equal doses of methylprednisolone sodium succinate (MPSS) were applied, i.e. $40 \mathrm{mg}$ it total per animal. In all pigs artificial inflammation of knee and elbow joints was provoked four days prior to the treatment. Four hours after the application of methylprednisolone tissue samples (both synovial fluid and hyaline cartilage) were obtained from the inflamed joints and subjected to analysis. The quantification of the drug was performed by HPLC technique. The results indicated high quantities of methylprednisolone both in the synovial fluid and hyaline cartilage, the concentrations being significantly higher in animals after iontophoretic application (17.15 \pm 3.11 and $12.70 \pm 2.19 \mu \mathrm{g} / \mathrm{g}$, respectively) in comparison with the animals treated intravenously $(0.33 \pm 0.11$ and $0.21 \pm 0.06 \mu \mathrm{g} / \mathrm{g}$, respectively). Thus, iontophoresis was proved a highly advisable clinical means of application of methylprednisolone, especially having in mind the possibility of avoiding systemic adverse effects which are present after parenteral drug administration. In addition, it enables higher therapeutic concentrations of MPSS to be obtained both in the synovial fluid and in the hyaline cartilage of the treated inflamed joints.

Key words: iontophoresis, methylprednisolone, inflamed joints, domestic pig

\section{INTRODUCTION}

The concentration of any drug in target tissues depends not only on its pharmacokinetics, but on the dose applied and on the route of administration, as well. Medications can enter the target tissues basically in a few ways: via mucous membranes (of the alimentary or respiratory tracts), via the skin or from the injection site (i.v., i.m., s.c., intra-articular). The penetration of drugs through skin 
can be enhanced by ultrasound (phonophoresis) or by galvanic currents i.e. by iontophoresis (Scheindlin, 2004).

lontophoresis (IPh) is a safe and non-invasive method of application of medicines deploying galvanic currents and has been widely used in the rehabilitation of patients (Banga and Panus, 1998). The potential gradient results into the migration of ionized active substances from opposite poles into the adjacent tissues. Thus, the activity of drugs is improved and the duration of their action is longer in comparison with those achieved by other ways of application. Such a means of drug administration enables to bypass the systemic circulation and avoids adverse effects, for example anaphylactic reactions, painful pin-pricks and emesis. In addition, maximal concentrations of the drug applied can be achieved locally in the tissue (Singh and Maibach, 1994).

Drugs applied by transdermal iontophoresis should be hydrosoluble, their ions of small masses, having high levels of dissociation. Furthermore, it is of utmost importance to know in which way the active substance dissociates in order to place it on the appropriate, "sending" electrode. In addition, the individual reactivity of different parts of body skin and their innervations are to be known (Todorov, 1994). Adequate use of IPh presumes that the skin must be prepared (shaved, disinfected). Otherwise, burns and damages of the skin are unavoidable. Drug delivery can be more efficacious if infra red light is used prior to IPh. This way of drug application is comfortable, avoiding any allergic or systemic reaction to various medications. In addition to this, IPh is an economical way of applying drugs, since in lower doses they exert better effects than when used parenterally (Djurdjević, 2001). The drawbacks of electrophoresis are its duration (15 to 20 minutes) and the need of an adequate apparatus (although inexpensive), the necessity of skin preparation and, finally, the fact that the bio dose depends on animal species, age, body mass, body area etc., which are to be known. These are the reasons for IPh being inapplicable simultaneously to more joints and tissues.

Methylprednisolone (MP) is a glucocorticoid with pronounced antiinflammatory and immunosuppressive effects achieved by several mechanisms. It decreases vascular permeability and inhibits the migration of polymorphonuclears, suppresses cell-mediated immunity by inducing apoptosis in lymphoid cells, inhibiting the clonal expansion of $T$ and $B$ cells, and reducing the amount of circulating eosinophils, basophils and monocytes. Furthermore, in inflamed tissues, methylprednisolone inhibits phagocytosis and oxygen-free radical production in macrophages and monocytes. Its glucocorticoid activity is about five times as high as of cortisole, but the mineralocorticoid activity lasts only half the same. Its anti-inflammatory effect lasts for 12 to 36 hours (Ferguson and Hoenig, 2001; The Merck Veterinary Manual). Methylprednisolone sodium succinate (MPSS) is the form of MP applicable intravenously.

The goal of this research was the measurement of intra-articular concentration of MPSS after intravenous (i.v.) application and after application by $\mathrm{EF}$. 
Acta Veterinaria (Beograd), Vol. 59. No. 2-3, 157-165, 2009.

\section{MATERIAL AND METHODS}

Chemicals

MPSS was obtained from Hemofarm (Lemod Solu) and turpentine from Florame (Turpentine organic essential oil) and dissolved in liquid paraffin (SigmaAldrich) to a concentration of $10 \%$. The animals were tranquillised with azaperone (Stresnil, Janssen Animal Health) and the skin disinfected with povidone iodine solution (Povidon jod, Zorka Pharma, Serbia).

\section{Animals}

Fourteen eight-week-old male pigs were involved, crossbreeds of the big Yorkshire and Swedish landrace, weighing $24.5 \mathrm{~kg}$ on average and alloted into two equal groups ( $A$ and $B$ ). The animals were kept and treated in accordance with The European Convention for the Protection of Vertebrate Animals used for Experimental and Other Scientific Purposes (The European Convention). Food and water were given ad libitum.

\section{Experimental protocol}

Half an hour before any treatment the pigs were tranquillised with azaperone ( $2 \mathrm{mg} / \mathrm{kg}$ bw, i.m). In order to provoke artificial inflammation four days prior to the administration of MPSS all the animals were applied $0.2 \mathrm{~mL}$ of $10 \%$ turpentine intra-articularly into the left elbow joint and contralateral knee joint. The temperature of the inflamed joints was measured by digital cutaneous thermometry. The inflammation was confirmed by histological examination of the joint tissues obtained by biopsy (Vangsness et al., 1997).

All the pigs were administered $40 \mathrm{mg}$ MPSS, the animals in group A intravenously (jugular vein), and in group B by iontophoresis, upon the affected joints. The cathode was wrapped in four-layer sterile gauze moistened with physiological saline. The electrodes made of rubber carbon fibres were attached to the opposite sides of the joint and fixed with rubber bandage on previously shaved and disinfected skin. The area of the positive electrode was $48 \mathrm{~cm}^{2}$ and of the negative one $63 \mathrm{~cm}^{2}$. Galvanic electric current (intensity $7.5 \mathrm{~mA}$ ) was applied for 15 min. (Hayashi et al., 1997). MP was sent from the cathode. In order to shorten the process of IPh and to improve the effect of the treatment, infrared rays were applied prior to the IP (distance from the skin $50 \mathrm{~cm}$, duration $10 \mathrm{~min}$ ).

Five, 10 and 15 minutes after the cessation of iontophoretic application of MPSS, samples of synovial fluid were taken from the joints and submitted to the evaluation of MPSS concentrations.

In addition, four hours after the drug application the pigs underwent punctures of the affected joints. The obtained tissue samples (synovial fluid and hyaline cartilage) were subjected to the determination of the concentration of MPSS and histological investigation (Maitland, 1986; Berkow, 1987). 


\section{Chemical analysis}

The identification and quantification of MPSS in the inflamed joints (synovial fluid and hyaline cartilage) were done by fluid-mass spectrometry on HPCL Waters 2695 Alliance system, supported with ZQ Mass Detector WATERS - Single quadropo.

\section{Statistical analysis}

The data were statistically processed by paired Student's t-test for small samples and analysis of variance (SPSS 17).

\section{RESULTS}

The concentrations of MPSS in the two biologically most important structures of the joint, the synovial liquid and hyaline cartilage, were determined after either intravenous or local, iontophoretic application into affected joints. Quite expectedly, the intraarticular administration of turpentine resulted in inflammation of the elbow and knee joints, which was ascertained by histological analysis.

The iontophoretic application of MPSS resulted in the mean concentration of $17.15 \mu \mathrm{g} / \mathrm{g}$ of this corticosteroid in the synovial fluid of inflamed joints, whereas the corresponding concentration was $0.33 \mu \mathrm{g} / \mathrm{g}$ when the intravenously drug applied (Table 1). The difference in these concentrations was statistically significant $(p<0.001)$.

Table 1. Average concentrations of MPSS in the synovial fluid of inflamed joints after different routes of application (i.v. and iontophoretic)

\begin{tabular}{|l|c|c|c|c|}
\hline & \multicolumn{2}{|c|}{ Route of administration } & \multirow{2}{*}{ Probability } & \multirow{2}{*}{ Significance } \\
\cline { 2 - 3 } & i.v. & Iph & t-test & $\mathrm{p}$ \\
\hline \hline $\begin{array}{l}\text { Statistical } \\
\text { parameters }\end{array}$ & $\mathrm{X} \pm \mathrm{SD}$ & $\mathrm{X} \pm \mathrm{SD}$ & 14.489 & $<0.001$ \\
\hline $\begin{array}{l}\text { Concentration of MPSS } \\
\text { in the synovia }(\mu \mathrm{g} / \mathrm{g})\end{array}$ & $0.33 \pm 0.11$ & $17.15 \pm 3.11$ & $<$ \\
\hline
\end{tabular}

It was also possible to compare the concentrations of MPSS in the hyaline cartilage of artificially inflamed joints, after various routes of application. Thus, the average concentration of the corticosteroid in the cartilage reached $0.21 \mu \mathrm{g} / \mathrm{g}$ after intravenous administration and as much as $12.70 \mu \mathrm{g} / \mathrm{g}$ following iontophoresis (Table 2), which was significantly higher in comparison with the former concentration.

In addition to the aforementioned, the concentrations of MPSS administered topically in the solid tissue and the liquid component obtained by joint punction underwent comparison (Table 3). Student's test revealed a significant difference 
Acta Veterinaria (Beograd), Vol. 59. No. 2-3, 157-165, 2009.

Đurđević S et al:: The evaluation of the concentrations of methylprednisolone applied intravenously and by iontophoresis in the pig

$(p<0.007)$ in the mean concentrations, the first being $12.70 \pm 2.19 \mu \mathrm{g} / \mathrm{g}$ and the second $17.15 \pm 3.11 \mu \mathrm{g} / \mathrm{g}$.

Table 2. Average concentrations of MPSS in the hyaline cartilage of inflamed joints after different routes of application

\begin{tabular}{|l|c|c|c|c|}
\hline & \multicolumn{2}{|c|}{ Route of administration } & \multirow{2}{*}{ Probability } & \multirow{2}{*}{ Significance } \\
\cline { 2 - 3 } & i.v. & Iph & \\
\hline \hline Statistical parameters & $\mathrm{X} \pm \mathrm{SD}$ & $\mathrm{X} \pm \mathrm{SD}$ & t-test & $\mathrm{P}$ \\
\hline $\begin{array}{l}\text { Concentration of MPSS } \\
\text { in the cartilage }(\mu \mathrm{g} / \mathrm{g})\end{array}$ & $0.21 \pm 0.06$ & $12.70 \pm 2.19$ & 15.21 & $<0.001$ \\
\hline
\end{tabular}

Table 3. Comparison of concentrations of MPSS in synovial fluid and hyaline cartilage after iontophoretic application

\begin{tabular}{|l|c|c|c|c|}
\hline & \multicolumn{2}{|c|}{ Methylprednisolone sodium succinate } & \multirow{2}{*}{ Probability } & \multirow{2}{*}{ Significance } \\
\cline { 2 - 3 } & Hyaline cartilage & Synovial fluid & \\
\hline \hline $\begin{array}{l}\text { Statistical } \\
\text { parameters }\end{array}$ & $\mathrm{X} \pm \mathrm{SD}$ & $\mathrm{X} \pm \mathrm{SD}$ & t-test & $\mathrm{p}$ \\
\hline $\begin{array}{l}\text { Concentration in } \\
\text { the tissues }(\mu \mathrm{g} / \mathrm{g})\end{array}$ & $12.70 \pm 2.19$ & $17.15 \pm 3.11$ & 4.042 & $<0.007$ \\
\hline
\end{tabular}

Lastly, a one-way analysis of variance revealed the intergroup variability of MPSS concentrations in the synovial liquid applied by IPh 5, 10 and 15 minutes after the cessation of iontophoresis (Table 4). Statistically significant differences were proved in the time-dependent increase of the concentration of MPSS.

Table 4. Comparison of the concentrations of MPSS in the synovial fluid 5, 10 and 15 minutes after iontophoretic application

\begin{tabular}{|l|c|c|c|c|c|}
\hline & \multicolumn{3}{|c|}{$\begin{array}{c}\text { Time elapsed from the end of } \\
\text { the iontophoresis (minutes) }\end{array}$} & \multirow{2}{*}{ Probability } & \multirow{2}{*}{ Significance } \\
\cline { 2 - 5 } & 5 & 10 & 15 & & \\
\hline \hline $\begin{array}{l}\text { Statistical } \\
\text { parameters }\end{array}$ & $\mathrm{X} \pm \mathrm{SD}$ & $\mathrm{X} \pm \mathrm{SD}$ & $\mathrm{X} \pm \mathrm{SD}$ & $\mathrm{F}$ & $\mathrm{p}$ \\
\hline $\begin{array}{l}\text { Concentration } \\
\text { of MPSS }(\mu \mathrm{g} / \mathrm{g})\end{array}$ & $7.27 \pm 1.37$ & $12.20 \pm 1.50$ & $17.15 \pm 1.29$ & 88.68 & $<0.001$ \\
\hline
\end{tabular}

\section{DISCUSSION}

The aim of the present work was to evaluate of the concentrations of MPSS in the synovial fluid and hyaline cartilage in artificially inflamed joints of pigs. 
Methylprednisolone is a well known synthetic glucocorticoid that has been in use in human and veterinary medicine for the treatment of various severe musculoskeletal diseases such as arthritis of different ethiology (psoriatic, gouty and rheumatoid arthritis), bursitis and tendinitis (Wright et al., 1999; Ferguson and Hoenig, 2001; Drugs.com; Badsha et al., 2002; Monteiro de Castro et al., 2003). Despite its pronounced anti-inflammatory effect, there are certain disadvantages to its application, local (such as ulcerative oesophagitis, abdominal distention) along with systemic (for example sodium and fluid retention, hypertension, hyperglycaemia, increased intraocular pressure, loss of muscular mass), often seen after repeated therapy (Methylprednisolone, http://www.drugs.com; http://www.umm.edu).

Comparison of average concentrations of MPSS in the synovial fluid and hyaline cartilage of inflamed knee and elbow joints in pigs after two different administration routes revealed higher concentrations after local application enhanced by galvanic currents. Thus, in the hyaline cartilage the average concentration of MPSS following topical administration was $12.70 \pm 2.19 \mu \mathrm{g} / \mathrm{g}$ in comparison with $0.21 \pm 0.06 \mu \mathrm{g} / \mathrm{g}$ after i.v. application of MPSS in the same dose, i.e. approximately 60 times higher.

In the synovial fluid the average concentration of MPSS reached $17.15 \pm 3.11 \mu \mathrm{g} / \mathrm{g}$ after the iontophoretic application and only $0.33 \pm 0.11 \mu \mathrm{g} / \mathrm{g}$ after intravenous. The former concentration, following local application, was 52-fold higher than the one resulting from i.v. application. Hence, the difference in concentrations in the synovial fluid was statistically significant.

Predictably, the concentration of MPSS was significantly higher in the synovial fluid than in the hyaline cartilage of the pigs treated by iontophoresis $(17.15 \pm 3.11 \mu \mathrm{g} / \mathrm{g}$ vs. $12.70 \pm 2.19 \mu \mathrm{g} / \mathrm{g})$.

Since there are no blood or lymph vessels in the cartilage, perfusion is only possible from the synovial fluid and blood vessels of the subchondral bone. Therefore the concentration of MPSS in the cartilage will continuously increase resulting in higher concentration in synovial fluid due to osmotic process, even after IPh or intravenous application of MPSS ceased. In our research a timedependent increase of MP concentrations in the synovial fluid was proved after the cessation of iontophoresis. The average concentrations obtained were 7.27, 12.20 and $17.15 \mu \mathrm{g} / \mathrm{g} \mathrm{5}, 10$ and 15 minutes after iontophoresis had finished, correspondingly.

Iontophoresis has certainly evolved into an attractive method for enhanced drug delivery especially for local anaesthesia prior to minor surgeries (Greenbaum, 2001) and topical anaesthesia which leads to acute and chronic pain relief (Zaciewski et al., 2007). In addition, MPSS has been successfully applied by iontophoretic means into the back eye of the rabbit with considerable results (Eljarat et al., 2008; Behar-Cohen et al., 2002), as well as used for pain relief in postherpetic neuralgia (Ozawa et al., 1999). Hereby we proved the feasibility of topical MPSS administration enhanced by galvanic current into the affected joint tissues. Iontophoresis represents a meaningful way of application avoiding systemic absorption and chances of expressing adverse effects, and, on the other hand, ascertaining high concentrations of MP in target tissues. 
lontophoresis is a painless, non-invasive means of application of drugs which can be delivered even to body parts difficult do approach, such as tarsal joints or tissues around the hooves. Furthermore, any infection is virtually impossible, high concentrations of MPSS are easily achieved while the concentrations in the systemic circulation are minimal, resulting in slight chances of adverse reactions.

Iontophoretic application of MPSS is advisable particularly in cases of arthritis of different etiology (degenerative, rheumatoid and other non-bacterial), which affects two or more joints. IPh can be performed to humans and animals, safely and harmlessly provided that for the affected species the thresholds are known. Even horses readily tolerate the use of electrical currents for drug transfer (Powell, 2008).

Given the fact that the use of iontophoresis in the horse is somewhat anecdotal and the results contradictory (Blackford et al., 1999), further investigations are required in this field. Nevertheless, we proved that maximum therapeutic concentrations of MPSS are easily achieved in both hyaline cartilage and synovial fluid when applied by IPh.

Last, but not least, in comparison with systemic administration, antiinflammatory drugs delivered by IPh produce remarkable therapeutic effects in lower doses, which is an additional important financial benefit in veterinary medicine.

Having in mind the aforementioned, we can certainly recommend the topical, iontophoretic use of MPSS in the therapy of disorders of the musculoskeletal system and in rehabilitation medicine of animals and humans. Furthermore, the current insight into the MPSS kinetics in the joints of pigs gave grounds to its iontophoretic application in humans prior to meniscectomy, which is being investigated and the results are to be published in the near future.

ACKNOWLEDGEMENTS

This research was financially supported by the Ministry of Science of Serbia, Project Grant No. 20142.

Address for correspondence:

Prof. Dr. Milanka Jezdimirovic

Faculty of Veterinary Medicine

Bulevar oslobodjenja 18

11000 Belgrade, Serbia

E-mail: milanka@vet.bg.ac.yu

\section{REFERENCES}

1. Badsha H, Kong KO, Lian TY, Chan SP, Edwards CJ, Chng HH, 2002, Low-dose pulse methylprednisolone for systemic lupus erythematosus flares is efficacious and has a decreased risk of infectious complications, Lupus, 11, 8, 508-13.

2. Banga AK, Panus PC, 1998, Clinical applications of iontophoretic devices in rehabilitation medicine, Crit Rev Rehab Med, 10, 147-79.

3. Behar-Cohen FF, El Aouni A, Gautier S, David G, Davis J, Chapon P et al, 2002, Transscleral Coulomb-controlled iontophoresis of methylprednisolone into the rabbit eye: influence of duration of treatment, current intensity and drug concentration on ocular tissue and fluid levels, Exp Eye Res, 74, 1, 51-9. 
4. Berkow R, 1987, Musculosceletal and connective tissue disorders, In Berkow R (ed): The Merck Manual, New York, Merck Manual, Merck Sharp \& Dohme Research Laboratories, 1304-10.

5. Blackford JT, Doherty TJ, Freslew KE, Panus PC, 1999, Dexamethasone iontophoresis in the equine tibiotarsal joint, reprint from IVIS (=International Veterinary Information Service) Online, Retrieved 18 Nov, 2008 from http://www.ivis.org/proceedings/aaep/1999/172.pdf

6. Đurđević $S$, 2001, Istraživanje uticaja fizikalnih agenasa na laktaciju, Doktorska disertacija, Medicinski fakultet Univerziteta u Nišu, 35-42.

7. Eljarat-Binstock E, Orucov F, Frucht-Pery J, Pe'er J, Domb AJ, 2008, Methylprednisolone delivery to the back of the eye using hydrogel iontophoresis, J Ocul Pharmacol Th, 24, 3, 344-50.

8. Ferguson DC, Hoenig M, 2001, Glucocorticoids, mineralocorticoids, and steroid synthesis inhibitors. In Adams HR, editor, Veterinary pharmacology and therapeutics, $8^{\text {th }}$ ed, Ames: lowa State University Press, 649-71.

9. Greenbaum SS, 2001, Iontophoresis as a tool for anesthesia in dermatologic surgery: An overview : Anesthesia, Dermatol Surg, 27, 12, 1027-30.

10. Hayashi K, Thabit G, Massa KL, 1997, The effect of thermal heating on the length and histologycal properties of the glenohumeral joint capsule, Am J Sports Med, 25, 107-12.

11. Maitland GD, 1986, Le genou, In: Corriggan B, Maitland GD, (eds): Medicine ortopedique pratique, Masson, Paris, 166-79.

12. Methylprednisolone. (2008) In Drugs.com. Drugs Information Online. Retrieved 17 Nov, 2008 from http://www.drugs.com/pro/methylprednisolone.html

13. Methylprednisolone. (2008) In The Merck Veterinary Manual Online. Retrieved 10 Nov, 2008 from http://www.merckvetmanual.com/mvm/index.jsp?cfile =htm/bc/191604.htm\&word=methylpr ednisolone

14. Methylprednisolone. (2008) In University of Meryland Medical Center. Retrieved 17 Nov, 2008 from http://www.umm.edu/altmed/drugs/methylprednisolone-085500.htm

15. Monteiro de Castro TC, Terreri MT, Len C, Esteves Hilário ME, 2003, Treatment of refractory juvenile idiopathic arthritis via pulse therapy using methylprednisolone and cyclophosphamide, Sao Paulo Med J, 121, 3, 117-20.

16. Ozawa A, Haruki Y, Iwashita K, Sasao Y, Miyahara M, Sugai J et al, 1999, Follow-up of clinical efficacy of iontophoresis therapy for postherpetic neuralgia (PHN), J Dermatol, 26, 1, 1-10.

17. Powell D. A New Look at Iontophoresis for Equines. Retrieved 18 Nov, 2008 from http://therapyproducts.net/New\%20Look.pdf

18. Scheindlin S, 2004, Transdermal drug delivery: past, present, future, Mol Interv, 4, 308-12.

19. Singh P, Maibach HI, 1994, lontophoresis in drug delivery: basic principles and applications, Crit Rev Ther Drug Carrier Syst, 11, 161-213.

20. SPSS Grad Pack 17.0 for Windows

21. The European Convention for the Protection of Vertebrate Animals used for Experimental and Other Scientific Purposes. (2008) In Conventions, Council of Europe Online. Retrieved 5 Nov, 2008 from http://conventions.coe.int/treaty/en/Treaties/Html/123.htm

22. Todorov N, 1994, Elektroterapia In: Nikolova L, Jonkov S, Todorov N (eds), Fizioterapija, Medicina i fizkultura, Sofija, 9-18.

23. Vangsness Ct, Mitchell W, Nimni M, 1997, Collage shortening : an experimental approach with heat, Clin Ortop, 337, 267-71.

24. Wright JP, Winter TA, Candy S, Marks I, 1999, Sucralfate and Methylprednisolone Enemas in Active Ulcerative Colitis (A Prospective, Single-Blind Study), Digest Dis Sci, 44, 9, 1899-901.

25. Zaciewski T, Brickman K, Wellock AR, Adams DZ, 2007, The use of iontophoresis in the pain management of soft tissue injuries in the emergency department: A pilot study, J Emerg Med, MEMC IV Abstracts, 330-1. 
Acta Veterinaria (Beograd), Vol. 59. No. 2-3, 157-165, 2009.

Đurđević $\mathrm{S}$ et al.: The evaluation of the concentrations of methylprednisolone

applied intravenously and by iontophoresis in the pig

\title{
EVALUACIJA KONCENTRACIJE METIL-PREDNIZOLONA POSLE INTRAVENSKE I ELEKTROFORETSKE APLIKACIJE KOD DOMAĆE SVINJE
}

\author{
ĐURĐEVIĆ S, JEZDIMIROVIĆ MILANKA, ĐUROVIĆ A, DEDIĆ GORDANA, \\ ALEKSIĆ NEVENKA, BRANKOVIĆ NATAŠA, STOJILJKOVIĆ S I STOJŠIĆ D
}

\section{SADRŽAJ}

Ispitivana je farmakokinetika metil-prednizolona na svinjama muškog pola kojima je ovaj lek aplikovan intravenski ili lokalno, putem elektroforeze. Metilprednizolon-natrijum-sukcinat primenjen je jednokratno, u dozi od 40 mg po životinji. Četiri dana pre tretmana, kod svih svinja je izazvano arteficijelno zapaljenje kolenog i lakatnog zgloba. Četiri sata posle aplikacije metil-prednizolona uzorci tkiva (sinovijalna tečnost i hijalina hrskavica) uzeti su iz inflamiranih zglobova i zatim analizirani. Kvantifikacija metil-prednizolona obavljena je HPLC metodom. Rezultati su ukazali na prisustvo visokih koncentracija metil-prednizolona u sinovijalnoj tečnosti i hijalinoj hrskavici, koje su bile statistički signifikantno veće posle elektroforetske aplikacije $(17,15 \pm 3,11$ u sinovijalnoj tečnosti i 12,70 $\pm 2,19 \mu \mathrm{g} / \mathrm{g}$ u hrskavici) u poređenju sa koncentracijama dobijenim posle intravenske primene $(0,33 \pm 0,11$ u sinovijalnoj tečnosti i 0,21 $\pm 0,06 \mu \mathrm{g} / \mathrm{g}$ u hrskavičnom tkivu). Iz ovog razloga, elektroforeza se preporučuje kao način lokalne aplikacije metilprednizolona kod inflamacije zglobova, naročito kada se ima u vidu mogućnost da se time izbegavaju sistemski neželjeni efekti koji nastaju posle parenteralne primene. Elektroforeza obezbeđuje vrlo visoke terapijske koncentracije metilprednizolon-natrijum-sukcinata kako u sinovijalnoj tečnosti, tako i u hrskavici tretiranih inflamiranih zglobova svinja. 